\title{
Professionals' and Students' Perceived Needs for an Online Supportive Application for Reducing School Absence and Stimulating Reintegration: Concept Mapping Study
}

Mariette H H Hoogsteder ${ }^{1}$, PhD; Linda N Douma ${ }^{1,2}$, PhD; Charlotte G A Eskens ${ }^{3}$, MSc; Renske L Berendsen ${ }^{4}$, MSc; Yvonne T M Vanneste ${ }^{5}$, MD, PhD; Frederieke G Schaafsma ${ }^{1}, \mathrm{MD}, \mathrm{PhD}$, Prof Dr

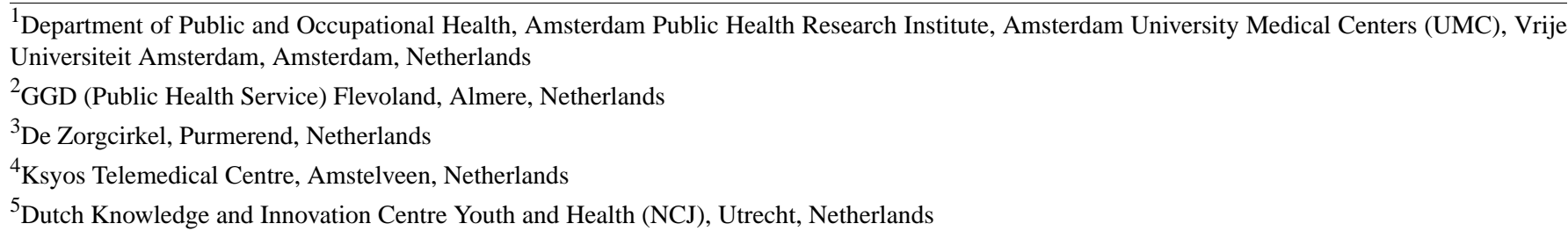

Corresponding Author:

Mariette H H Hoogsteder, PhD

Department of Public and Occupational Health

Amsterdam Public Health Research Institute

Amsterdam University Medical Centers (UMC), Vrije Universiteit Amsterdam

Van der Boechorststraat 7

Amsterdam, $1081 \mathrm{BT}$

Netherlands

Phone: 31204445965

Email: m.hoogsteder@amsterdamumc.nl

\begin{abstract}
Background: To limit students' medical absenteeism and premature school dropout in the Netherlands, the Medical Advice for Sick-reported Students (MASS) intervention was developed to enhance collaboration between students, parents, school, and health care professionals. MASS reduces medical absenteeism. However, it does not yet optimally support professionals in monitoring students nor automatically stimulating students' autonomy regarding their situation.
\end{abstract}

Objective: This study aimed to identify professionals' and students' perceived need for an online supportive application to monitor and reduce absenteeism and stimulate student autonomy and school reintegration.

Methods: Concept mapping sessions were held with professionals $(n=23)$ and secondary school students $(n=27)$ in group meetings or online to identify their perspectives and needs. Multidimensional scaling and hierarchical clustering were done with Ariadne 3.0 software. The resulting concept maps were reclustered and interpreted by 4 researchers.

Results: Three heterogeneous groups of professionals generated 17 clusters (135 unique statements), with a mean importance rating ranging from 2.9 to 4.6 on a Likert scale with scores ranging from 1 to 5 . Three heterogeneous groups of secondary school students generated 18 clusters (95 unique statements), with a mean importance rating ranging from 3.2 to 4.6. Professionals considered as most important the following: easily accessible contact with students; supporting, motivating, and rewarding students; monitoring absent students; providing information to students and their parents; exchanging information between professionals. Students considered as most important the following: better teacher-student communication and respect; communication between school professionals on the one hand and parents, other professionals, and students on the other hand; guidance in missed learning materials and tests. Students perceived an online format for support as the obvious option.

Conclusions: Both professionals and students were positive about an online application to support students in dealing with medical absenteeism, especially considering the need for better and easily accessible contact between students and professionals. An eHealth or mobile health (mHealth) application addressing these aspects could stimulate student autonomy and have positive effects on medical absenteeism. 


\section{KEYWORDS}

medical absenteeism; secondary education; eHealth; mHealth; mobile health; students; schools, health occupations; youth health physicians; concept mapping

\section{Introduction}

School absenteeism is a serious problem in many countries worldwide [1-3], including the Netherlands. Recent numbers show that, for example, in the United States, at least $13 \%$ of all students (5-18 years old) are chronically absent from school, involving both excused and unexcused absences as well as suspensions. In the Netherlands, no clear-cut definition of chronic absenteeism exists. Problematic absenteeism is defined as being absent from school for a minimum of 16 hours during a consecutive period of 4 weeks [4]. Recent numbers show that at least $5 \%$ of all students aged 5 to 18 years old is problematically absent from school $[5,6]$. However, this only involves unexcused absences and not absences because of illness or problems. Although Dutch schools are required to register both unexcused and excused absences, they only need to report chronic unexcused absences to the authorities [4]. Frequent and prolonged school absenteeism due to either unexcused or excused absences can have a significant impact on a student's life, for example leading to stagnation of a student's (learning) development, a lower education level, and even school dropout [7-10]. In the Netherlands, $2 \%$ of students attending secondary or vocational schools (12-23 years old) drop out prematurely, a number that is slowly increasing [5,6,11]. Successfully completing school and having a degree is important, as it will provide better employment opportunities, contributing to a better financial and living situation. Furthermore, people with a school diploma are less likely to exhibit delinquent behavior and more likely to continue studying and to live healthier and longer lives [12-18]. Subsequently, health outcomes can be improved by early diagnosis and management of specific physical and mental health problems associated with school absence [19] and by optimizing educational opportunities [20]. Therefore, school absenteeism and school dropout should be considered public health problems $[13,15,16,18]$.
Behind excused school absenteeism there may be many reasons, medical absenteeism being one of them. Medical absenteeism refers to students reporting absent from school because of (a wide range of) health-related problems $[1,12]$. Exact numbers relating to medical absenteeism are unclear, as schools are not required to report these to the Dutch authorities. Multiple factors are involved in chronic absenteeism, and schools may differ in how they report absence $[4,6,12]$. However, a World Health Organization report from 2002 [21] showed that, in half of the school absenteeism cases in Dutch secondary schools, being ill was reported as the cause. Additionally, a national health monitor study with students in the second and fourth grades of secondary school showed that in $40 \%$ of absentee cases, students reported that this was because of illness, while truancy was reported in $11 \%$ of the cases [22]. This indicates that, in secondary school, medical absenteeism is a significant and prevalent type of absenteeism. However, in most countries, the approach to reducing school absenteeism primarily focuses on truancy. Nonetheless, integrated solutions are being developed such as the involvement of physicians and (public) health services $[1,7,12]$. In the Netherlands, an integrated approach to addressing medical absenteeism has been developed, namely the Medical Advice for Sick-reported Students (MASS) intervention [23,24] (see Figure 1 by Vanneste et al [25]). This intervention, as well as other school health care activities, is coordinated by the youth health care section of regional Public Health Services. The MASS intervention has dual purposes: (1) stimulating collaboration between professionals involved in the care of a medically absent student, in particular schools, youth health care, and the school attendance service, and (2) optimizing students' health, maximizing students' participation in school activities, and limiting school absenteeism for medical reasons [17,18,24,25]. 
Figure 1. Description of the Dutch intervention "Medical Advice for Sick-reported Students" (MASS) by Vanneste et al [25]. YHCP: youth health care provider.

The MASS intervention consists of an integrated approach in a public health setting. MASS provides a clear framework in which schools, in direct collaboration with YHCPs, are able to reach students and their parents, discuss aspects of the student's medical absence, and design and monitor a management plan that aims to optimize students' health and maximize students' participation in school activities. In summary, the aim of the MASS intervention is to limit the absenteeism by arranging appropriate care, educational adjustments and adequate support for students and parents. A systematic routine is followed.

\section{Step 1 School's policy}

The school communicates with students and parents about the new policy in case of absenteeism because of medical reasons.

\section{Step 2 Referral to the YHCP}

Students with extensive medical absence are identified by school by using well-defined threshold criteria: reported sick four times in 12 school weeks or more than six consecutive school days (MASS-criteria). Meeting the criteria always leads to a referral to the YHCP for student and parents.

\section{Step 3 Consultation of student and parents with the YHC}

During the interview and medical assessment YHCPs look for biological, psychological and social factors that contribute to the students' medical absenteeism. The YHCP identifies whether there is a specific somatic or psychiatric diagnosis to account for the absence. If the diagnosis is clear the focus will be on optimising the (adherence to) treatment. In cases of frequent physical complaints and psychosocial problems with no clear medical diagnosis, the YHCP considers diagnostics, and looks for family-related and schoolrelated, as well as health risk behaviours and lifestyle aspects that contribute to the physical complaints and psychosocial problems. If needed, the YHCP refers to a medical specialist or a psychosocial support network. A management plan is then designed together with student, parents and school, and with curative professionals, if applicable. This plan includes agreements on cure, care and school attendance.

\section{Step 4 Monitoring the management plan}

School and YHCP monitor the execution of the management plan.

The MASS intervention shows promising effects regarding the reduction of absenteeism in secondary schools for medical reasons [25-27]. However, certain aspects of the intervention could still be further improved, for example, regarding the monitoring of students and stimulating students' autonomy regarding their situation, as well as regarding the collaboration between professionals [28]. Many different professionals are involved in the MASS intervention and the care and support of students frequently absent from school. This makes collaboration and the alignment of efforts more complex, but also more necessary [29]. eHealth and particularly mobile health (mHealth) could be used to support communication and collaboration between all professionals involved [30,31]. Additionally, it could have beneficial effects for students. According to the European Commission, mHealth has a preventive function and adds value to patient-focused care [32]. mHealth has a broad 
reach, can be tailored, is easily accessible, appeals to a person's autonomy, and is relatively low in cost $[28,30,33]$. Furthermore, mHealth is considered a low threshold tool to access information, change behavior, and monitor and guide a person from a distance [28]. All these aspects would make eHealth or mHealth an appealing tool for both professionals and students to use as support in reducing school absenteeism and stimulating student autonomy, especially in the Netherlands, where over $93 \%$ of students use the internet daily [34]. Therefore, a supportive online application might be a helpful tool to complement the MASS intervention and enhance its effects regarding the reduction of school absenteeism and school dropout.

To develop a relevant and effective online application to complement the MASS intervention, it is key to first explore and take into account the perspectives and needs of the target population [35,36]: professionals in the field of school absenteeism and students. Therefore, our study focused on the following research questions:

1. What are the perspectives and needs of professionals involved in the care of an absent student concerning an online application aimed at reducing school absenteeism, stimulating student autonomy, and stimulating school reintegration?

2. What are the perspectives and needs of students concerning an online application aimed at reducing school absenteeism, stimulating student autonomy, and stimulating school reintegration?

\section{Methods}

\section{Design}

This study followed an exploratory descriptive design. To examine the perceptions of relevant stakeholders, the participatory research method of concept mapping was used $[37,38]$. Concept mapping has been widely applied in health care-related research for this purpose [39]. Concept mapping consists of 6 steps: (1) preparation, (2) generation of statements, (3) structuring of statements, (4) analysis and representation of statements in the form of a concept map, (5) interpretation of the maps, (6) utilization of maps. A qualitative method is used to collect group data (ie, perspectives/statements from the group) following an inductive and structured approach. Quantitative analysis is then used to generate a representation of the collected statements in the form of a concept map. To interpret the generated concept maps, qualitative analysis is used.

\section{Recruitment of Participants}

For our study, we recruited professionals involved in the care or support of absent students, as well as students currently attending secondary school. Concept mapping sessions were conducted with both target groups independently from each other to ensure that they could speak freely, as the hierarchy between students and professionals may affect the group dynamics and responses given. All concept mapping sessions were facilitated by CE and RB. Regarding both target groups, we aimed for a heterogeneous group of participants, to stimulate discussion and provide a more comprehensive and diverse range of perspectives. Participants for both target groups were recruited in the period of February 2018 and March 2018.

With the Public Health Service Flevoland (GGD Flevoland) as our base, we recruited professionals and students from the 2 largest cities in the Flevoland province: Almere $(205,000$ inhabitants) and Lelystad (77,000 inhabitants) [40].

\section{Professionals}

The professionals were selected through purposive sampling, aiming to include 30 professionals with diverse job functions from various organizations relevant to (medical) school absenteeism or the MASS intervention (eg, youth health care physicians, teachers, school care coordinators, remedial educationalists, other health professionals, and school attendance officers). All professionals were recruited by email. Follow-up telephone calls were conducted with those who were nonresponsive to the initial email.

\section{Students}

To recruit students, we first contacted secondary schools_-varying in educational levels_-located in Almere and Lelystad by email. Follow-up telephone calls were conducted with those that were nonresponsive to the initial email. Eventually, 3 secondary schools were willing to participate. Once a school agreed to participate, the school sent their students a pamphlet and information letter concerning our study. Participants were promised a gift voucher of $€ 10$ after completion of the data collection.

\section{Ethics Approval}

The study protocol did not need approval by a Medical Ethics Review Committee because it did not fall within the legal scope of medical research involving human subjects. All students received an informational letter, and written informed consent was obtained before participation. If a student was under the age of 16 years, a parent or caregiver received an informational letter concerning our study as well and had to cosign the informed consent form.

To ensure anonymity and privacy of the participants, personal data and informed consent forms were stored in a secured file only accessible by the researchers. Other data such as fieldnotes and online input per email during the concept mapping were de-identified, removing names and other identifying data if necessary. All data were stored and processed on a secured network drive at the university.

\section{Concept Mapping Sessions}

All sessions followed a similar structure, using the 6 steps involved in concept mapping. We organized 3 concept mapping sessions with professionals (maximum of 2 hours). The first 2 sessions were physical meetings, and the third one was conducted online. We also conducted 3 concept mapping sessions with students at the 3 school locations. However, with Hidding et al [41] as an example, the concept mapping sessions conducted with the students were split into 2 parts because their attention spans can be more limited than that of adults. The first part (1 hour) consisted of the generation of statements (step 2 of concept mapping). The second part (1 hour) consisted of the 
structuring of statements (step 3). Between the first and second part was an intermission of 1-3 weeks.

\section{Step 1: Preparation}

Participants were selected, and the focus statement was formulated. A focus statement is used as a starting point in order to stimulate participants to "free associate" and to generate as many perspectives or statements as possible. The focus statement for the professional sessions was: "How can you support young people who are frequently or long-term (medically) absent from school with the help of a digital tool?"

The focus statement for the student sessions was intentionally formulated more broadly in order to explore their overall supportive needs and not only their need for an online application. Additionally, to enhance the understanding of the student participants, the same focus statement was formulated in 2 ways: (1) "How do I want school to help me when I am frequently or long-term ill?" and (2) "When I am frequently or long-term ill, I want school to help me with ..."

\section{Step 2: Generation of Statements}

Each concept mapping session started with an introduction to the topic and concept mapping. Then, participants were asked to respond to the focus statement and to generate as many statements as possible. Participants started with an individual brainstorm of approximately 10 minutes, after which they shared their responses in a group brainstorm. Participants were asked to share 1 statement at a time, after which the other participants could add something to this statement. In the online session (only with professionals), all the statements of the individual brainstorm were sent by email to the facilitators, who merged all the statements and subsequently shared all the statements with the group. Then, via email, participants could respond to the given statements and add new ones. Regarding all sessions, the final list of generated statements was reformulated, where necessary, by the session facilitators (CE and RB and discussed with $\mathrm{MH}$ and FS until consensus was reached) to keep the meaning of the statements clear and understandable for every participant.

\section{Step 3: Structuring of Statements}

The structuring of statements was conducted using the concept mapping software Ariadne 3.0 [42]. Participants first individually organized all statements generated in their session according to content, grouping statements into clusters of related statements. Subsequently, they each ranked the importance of all statements according to a 5-point Likert scale, where 1 represented "not important at all" and 5 represented "very important.'

\section{Step 4: Representation of Statements in the Form of a Concept Map}

Using Ariadne 3.0, a graphical representation of the statements was created in the form of a concept map [39]. All statements are presented as separate points in the visual representation/concept map. Statements that are frequently placed together are similar in content and presented more closely together on the concept map, resulting in clusters. Statements that are seldomly placed together by the participants are placed on the map opposite from each other. The analyses were conducted separately for each concept mapping session.

\section{Step 5: Interpretation of the Maps}

The interpretation of the final concept maps, in which the clusters (ie, themes) are named and discussed, was done by 4 researchers (CE, RB, FS, and $\mathrm{MH}$ ). Similarities between statements in every cluster were identified. The researchers named each cluster in the final concept maps by the overarching theme that it represented. Subsequently, the researchers critically contemplated the clusters generated by the software Ariadne 3.0, because some of the statements did not optimally suit a particular cluster. After deliberation and when consensus between the researchers was reached, some of the statements were moved to other clusters nearby, or new clusters were formed. Finally, using Ariadne 3.0, the average importance rates of the clusters were calculated to rank them from high to low.

\section{Step 6: Utilization of Maps}

The sixth and final concept mapping step, utilization of the maps, involves the identification of determinants that could be used for the development of a supportive mobile online application to complement the MASS intervention (see Discussion).

\section{Statistical Analysis}

The data from each concept mapping session were analyzed with the software program Ariadne 3.0 [42], which uses multivariate statistical techniques (multidimensional scaling and hierarchical clustering) to visually present statements generated in the group sessions. The analyses resulted in 1 concept map per session.

\section{Results}

\section{Participants}

\section{Professionals}

Overall, 23 professionals participated in our concept mapping sessions (Table 1). For the first session, 28 professionals were invited, of which 5 were able to participate. For the second session, 17 professionals were invited, of which 10 were able to participate. The third (online) session consisted of 8 professionals who were initially invited for the first or second session but could not participate earlier because of a busy work schedule. In this session, only 6 participants were involved with the clustering and prioritizing of the statements (step three of concept mapping), again because of a busy work schedule. The majority of our sample was female $(n=21)$, ranging from 27 to 60 years old and with an average work experience with school absenteeism of 9 (SD 6.4) years. The participants were professionals with diverse functions in 7 organizations and 6 schools (see Multimedia Appendix 1 for an overview of the professionals' job functions). 
Table 1. Sample characteristics of professionals $(n=23)$.

\begin{tabular}{ll}
\hline Characteristic & $\mathrm{n}(\%)$ \\
\hline Gender & $2(9)$ \\
$\quad$ Male & $21(91)$ \\
Female & \\
Age group (years) & $4(17)$ \\
$21-30$ & $6(26)$ \\
$31-40$ & $8(35)$ \\
$41-50$ & $5(22)$ \\
$51-60$ & $8(35)$ \\
Work experience with school absenteeism (years) & $6(26)$ \\
$<5$ & $8(35)$ \\
$5-10$ & $1(4)$ \\
$11-20$ & \\
$>20$ &
\end{tabular}

\section{Students}

Overall, 27 students participated in our study (Table 2), ranging in age from 13 to 18 years old, with the majority being female $(n=16)$. They attended 1 of the 3 participating secondary schools: (1) a special education school teaching at the general secondary level $(n=7) ;(2)$ a regular school teaching at various educational

levels $(n=11)$; (3) a regular school teaching at the prevocational secondary level $(n=9)$. The MASS criteria were met by 8 participants (see Figure 1, Step 2 [24,25]) of school absenteeism for medical reasons. Although 4 participants, of which 3 met the MASS criteria, were not able to attend the second part of the concept mapping session, 1 of them completed the session online.

Table 2. Sample characteristics of students $(n=27)$.

\begin{tabular}{ll}
\hline Characteristic & $\mathrm{n}(\%)$ \\
\hline Gender & $11(40)$ \\
Male & $16(60)$ \\
Female & \\
Age (years) & $5(18)$ \\
13 & $3(11)$ \\
14 & $1(4)$ \\
15 & $10(37)$ \\
16 & $7(26)$ \\
17 & $1(4)$ \\
18 & \\
Educational level & $16(59)$ \\
Pre-vocational secondary (Dutch: vmbo) & $7(26)$ \\
Higher general secondary (Dutch: havo) & $3(11)$ \\
Pre-university (Dutch: vwo) & $1(4)$ \\
Unknown & $7(26)$ \\
Special education (yes) & $8(30)$ \\
Meeting MASS & criteria (yes) \\
\hline
\end{tabular}

${ }^{a}$ MASS: Medical Advice for Sick-reported Students. 


\section{Concept Maps and Clusters}

\section{Professionals}

Three heterogeneous groups of professionals generated 135 unique statements, with an importance rating ranging from 1.6 to 4.8 on the Likert scale with scores ranging from 1 to 5 . These statements were combined into 17 clusters, with a mean importance rating ranging from 2.9 to 4.6 on the Likert scale with scores ranging from 1 to 5 (see Multimedia Appendix 2 for the corresponding concept maps). Table 3 presents the clusters relating to the perspectives and needs for a supportive tool in reducing school absenteeism mentioned by professionals. Important aspects as considered by professionals were (1) easily accessible contact with students; (2) supporting, motivating, and rewarding students; (3) monitoring absent students; (4) providing information to students and their parents; and (5) exchanging information between professionals.

Table 3. Clusters, associated example statements, and mean importance ratings per group concerning the perspectives and needs of professionals for a supportive tool in reducing school absenteeism.

\begin{tabular}{|c|c|c|}
\hline Cluster name & Example statement & Mean importance ${ }^{\mathrm{a}}$ \\
\hline \multicolumn{3}{|l|}{ Group 1} \\
\hline 1. Contact from (school) professional to student & An extra function for mentors to get in contact with the students & 4.6 \\
\hline 2. Reward system & A reward system when showing desired behavior & 4.2 \\
\hline 3. Contact from student to (school) professional & $\begin{array}{l}\text { The possibility for students to have easily accessible contact with } \\
\text { the outside world }\end{array}$ & 3.8 \\
\hline 4. Characteristics and functions of the application & User-friendly for all school levels & 3.7 \\
\hline 5. Exchange information between professionals & $\begin{array}{l}\text { An overview of concerned parties to improve the collaboration be- } \\
\text { tween professionals }\end{array}$ & 3.5 \\
\hline $\begin{array}{l}\text { 6. Responsibilities of involved youth health care } \\
\text { professionals }\end{array}$ & $\begin{array}{l}\text { Help from the youth health care nurse during start-up for students } \\
\text { to use the application }\end{array}$ & 3.2 \\
\hline $\begin{array}{l}\text { 7. Inform students and parents about school absen- } \\
\text { teeism }\end{array}$ & $\begin{array}{l}\text { To provide information about the consequences of school absen- } \\
\text { teeism, including appropriate tools }\end{array}$ & 3.2 \\
\hline \multicolumn{3}{|l|}{ Group 2} \\
\hline 1. Dossier access for professionals & $\begin{array}{l}\text { Access to the student's dossier so all involved parties can add sup- } \\
\text { plemental information }\end{array}$ & 4.1 \\
\hline $\begin{array}{l}\text { 2. Contact with students and other features of the } \\
\text { application }\end{array}$ & Direct lines with the students to make them feel noticed & 3.7 \\
\hline 3. Monitor absent students & A system to map the (absenteeism) developments of the students & 3.7 \\
\hline 4. A separate account for parents & A notification for parents about their child's school absenteeism & 3.2 \\
\hline $\begin{array}{l}\text { 5. Provide information and an overview of profes- } \\
\text { sionals involved }\end{array}$ & $\begin{array}{l}\text { An overview for students to understand precisely what is and is not } \\
\text { a legitimate reason for school absenteeism }\end{array}$ & 2.9 \\
\hline \multicolumn{3}{|l|}{ Group 3} \\
\hline $\begin{array}{l}\text { 1. Contact between (school) professionals and } \\
\text { students }\end{array}$ & Daily or more frequent contact with students who are absent & 4.3 \\
\hline 2. Support and motivate students & $\begin{array}{l}\text { Inclusion of self-set goals by the students in the tool, with indicators } \\
\text { if they are achieved or not }\end{array}$ & 3.7 \\
\hline $\begin{array}{l}\text { 3. Responsibilities of schools and other profession- } \\
\text { als }\end{array}$ & $\begin{array}{l}\text { Prevent students from long-term absenteeism by supporting them } \\
\text { in formulating their action plan and goals }\end{array}$ & 3.5 \\
\hline 4. Provide information and monitor absenteeism & $\begin{array}{l}\text { To provide students with advice, tailored to their problems, such as } \\
\text { problems with eating, sleeping, gaming, or mood swings }\end{array}$ & 3.5 \\
\hline 5. Involve parents and professionals & Support and unburden parents using the tool & 3.1 \\
\hline
\end{tabular}

${ }^{\text {a } R a t e d ~ o n ~ a ~ 5-p o i n t ~ L i k e r t ~ s c a l e ~ w i t h ~ h i g h e r ~ s c o r e s ~ i n d i c a t i n g ~ h i g h e r ~ i m p o r t a n c e . ~}$

The first aspect, easily accessible contact with students, refers to the professionals' reported need for a supportive online tool to be able to communicate and stay in contact with absent students in an easy and low-threshold way. Professionals expressed the belief that students should receive attention and support in an approachable and informal manner. Additionally, the application design should be appealing for and tailored to the target group of students.

The second, third, and fourth aspects (supporting, motivating, and rewarding students; monitoring absent students; and providing information to students and their parents, respectively) were closely related to each other, with all emphasizing the 
importance of adequately supporting, motivating, and monitoring students. Professionals expressed the importance of working with personal goals and a reward system when students show the behavior that brings them closer to their personal goals, for example, when they are present at school or doing schoolwork at home. Additionally, suggestions were made to add a game or reward element to motivate students to work on their goals and to continue using the tool. The ability to monitor students using a supportive tool would provide professionals with more insight into the frequency of school absenteeism and to what extent absent students experience physical and psychological symptoms. In addition, professionals mentioned a preference for a separate account for parents, enabling them to support their child with working on their goals, after their child gave permission. Furthermore, professionals expressed a need to provide information to both students and parents through an online tool, especially about the causes and consequences of school absenteeism and how to deal with common health and learning issues in general.

The fifth aspect, exchanging information between professionals, refers to professionals wanting to know which other care organizations or professionals are involved with a student and to be able to share relevant information with them-in a secure manner and with the student's informed consent - in order to improve collaboration and support for the student. The suggestion was to use the online tool to provide an overview and contact details of the professionals involved.

\section{Students}

Three heterogeneous groups of secondary school students generated 95 unique statements, with an importance rating ranging from 2.2 to 4.9 on the Likert scale with scores ranging from 1 to 5 . These statements were combined into 18 clusters, with a mean importance rating ranging from 3.2 to 4.6 on the Likert scale with scores ranging from 1 to 5 (see Multimedia Appendix 3 for the corresponding concept maps). Table 4 presents the clusters relating to the perspectives and needs for a supportive tool in reducing school absenteeism mentioned by students. Important aspects as considered by students were (1) respect and better teacher-student communication; (2) communication between school on the one hand and parents, professionals, and students on the other hand; and (3) guidance for missed learning materials and tests. They perceived an online format as a supportive tool as undoubtedly the obvious option. 
Table 4. Clusters, associated example statements, and mean importance ratings per group concerning the perspectives and needs of students for a supportive tool in reducing school absenteeism.

\begin{tabular}{|c|c|c|}
\hline Cluster name & Example statement & Mean importance ${ }^{\mathrm{a}}$ \\
\hline \multicolumn{3}{|l|}{ Group 1} \\
\hline 1. Training teachers & Training teachers to support students in returning to school & 4.2 \\
\hline 2. Counsellor & You should get along with your counsellor & 3.8 \\
\hline 3. Information for parents & $\begin{array}{l}\text { Overview for parents of when their child has to go and does not } \\
\text { have to go to school }\end{array}$ & 3.6 \\
\hline 4. Dossier & Information in the dossier is confidential and well-protected & 3.6 \\
\hline 5. Missed learning materials and tests & Review of missed learning materials provided by school & 3.4 \\
\hline 6. Contact between teachers and students & Teachers are better informed on what is going on with the student & 3.2 \\
\hline 7. Independent case management & $\begin{array}{l}\text { Improve and expedite the communication between school and } \\
\text { attendance officer }\end{array}$ & 3.2 \\
\hline \multicolumn{3}{|l|}{ Group 2} \\
\hline 1. Communication and respect & Equal rights and rules for students and teachers & 4.6 \\
\hline 2. Registration of medical absence & Easier logging in and out & 4.4 \\
\hline 3. Schedule & Access to correct school schedule & 4.4 \\
\hline 4. Overview of missed learning materials & Online summary of missed learning materials available & 4.2 \\
\hline 5. Alleviating the rules on absenteeism & $\begin{array}{l}\text { Maintaining the opportunity to do a makeup test when you missed } \\
\text { a test due to illness }\end{array}$ & 4.1 \\
\hline 6. Preparations for a test & $\begin{array}{l}\text { Having the option to review a test before the next one to be able } \\
\text { to prepare better }\end{array}$ & 3.9 \\
\hline 7. Communication during absenteeism & Weekly check-in by school how the absent student is doing & 3.6 \\
\hline \multicolumn{3}{|l|}{ Group 3} \\
\hline $\begin{array}{l}\text { 1. Keeping up with learning materials and } \\
\text { more fun classes }\end{array}$ & More fun classes help to pay attention and to return to school & 4.0 \\
\hline 2. Respect and rules on absenteeism & Teachers have to treat students respectfully & 3.8 \\
\hline 3. Online features & $\begin{array}{l}\text { One working app that displays the schedule, homework, grades, } \\
\text { and missed information }\end{array}$ & 3.6 \\
\hline 4. Makeup tests & Offering makeup tests for a longer period of time & 3.2 \\
\hline
\end{tabular}

${ }^{\text {a } R a t e d ~ o n ~ a ~ 5-p o i n t ~ L i k e r t ~ s c a l e ~ w i t h ~ h i g h e r ~ s c o r e s ~ i n d i c a t i n g ~ h i g h e r ~ i m p o r t a n c e . ~}$

The first 2 aspects (respect and better teacher-student communication; communication between school on the one hand and parents, professionals, and students on the other hand) refer to students' reported need for teachers to be better informed about a student's situation and well-being and to improve communication between all parties involved (ie, school, students, parents, other professionals). Students expressed a desire for equal rights, rules, and respect between teachers and themselves and a preference to be able to ask their teacher questions through an easily accessible (online) tool. Students also believed that schools should ask in-depth questions about their reason for their absence and expressed a need for earlier communication by the school regarding a possible change in their schedule.

The third aspect (guidance for missed learning materials and tests) refers to students' expressed need for an overview of the missed learning materials and a main contact person from which to receive relevant notes, learning materials, and homework. Additionally, students expressed a desire for take-home tests

and an extension of the period to take tests that they missed. The fourth aspect (online support as obvious) refers to the students' preferred supporting format, namely online. Students mentioned that one comprehensive application is necessary, providing them access to their schedule, homework, grades, and (missed) learning materials. They also discussed the need for a forum where they can post questions to their peers and teachers.

\section{Discussion}

\section{Principal Findings}

Both professionals and students expressed positive perceptions and identified added value regarding an online application to support students in dealing with school absenteeism for medical reasons and to stimulate student autonomy and return to school. The most important aspects of a supportive eHealth or mHealth application as considered by professionals were easily accessible contact with students; supporting, motivating, and rewarding students; monitoring absent students; providing information to 
students and their parents; and exchanging information between professionals. The most important aspects as considered by students were better teacher-student communication and respect; communication between school on the one hand and parents, professionals, and students on the other hand; and guidance for missed learning materials and tests. Furthermore, students perceived an online format as a supportive tool as undoubtedly the obvious and self-evident option.

A shared need among professionals and students in our study was the fostering of better and easily accessible contact between students, parents, and professionals involved, preferably using online facilities. Previous research on the needs of health care professionals relating to patient care and the use of eHealth or mHealth also found easily accessible contact to be an important need [35,43]. Additionally, studies reviewing the impact of mHealth interventions worldwide reported that the use of mHealth can improve communication with and between health care professionals [30,44]. Furthermore, previous research within the context of school absenteeism and dropout also confirms the importance of easily accessible contact between students, parents, and professionals. Positive teacher-student contact contributes to students feeling supported, empowered, and engaged in school, as well as a reduction of school absenteeism [45-48]. e-Learning and other online tools can facilitate establishing this contact and related benefits $[49,50]$. In addition, better communication between schools and parents contributes to parental involvement, which has shown to be beneficial to students' school engagement and reduced absenteeism [46,51,52]. The benefits of better and easily accessible contact between all parties involved relate to the monitoring, supporting, motivating, and guiding of students in general, which are all aspects of a supportive online application considered important by professionals and or students in our study.

The importance of easily accessible contact is also supported by research on occupational health [53-55], which appears to have relevant similarities to the context of school absenteeism. From the occupational health research, it is known that keeping in touch with medically absent workers on a regular basis and providing supervisor or co-worker support helps with the return to work or being able to continue working when chronically ill [53]. Additionally, these studies have shown that it is beneficial for the absent worker to discuss returning to work with their employer and to receive information on the recovery process as well as on sick leave procedures. Also, if necessary, an occupational health physician will be involved [54,55]. For an absent worker, it is just as essential as it is for students that contact and communication between all parties involved is done with respect, taking the perspective of the absentee as a starting point [53,55].

The perceptions and needs expressed by professionals and students in our study relate to key elements of the MASS intervention, particularly communication, motivation, individual monitoring/guidance, early detection of absence, and professional collaboration [24-27], with the addition of incorporating online facilities. The MASS intervention is promising in reducing medical absenteeism in secondary schools [25-27], but aspects such as the monitoring of students, stimulating students' autonomy, and collaboration between professionals could be further improved [28]. The findings from our study indicate that these specific aspects could be addressed with the use of an online application, which is supported by many previous studies showing eHealth or mHealth and online tools to have an empowering and facilitating effect [28,30-33,50,56-59]. Therefore, developing an online application complementary to the MASS intervention could potentially stimulate and enhance the intervention's positive effects on school absenteeism, especially when the online application can be tailored to students' unique sets of reasons behind their absenteeism and their individual needs [45].

\section{Strengths and Limitations}

To our knowledge, this is the first study to apply concept mapping to examine professionals' and students' perspectives regarding (medical) school absenteeism as well as the use of an online tool. Our study has several strengths. First, our study samples of professionals and students were relatively heterogeneous (differing in age, education level, experience with school absenteeism, school location, organization, job function, and work experience), increasing the generalizability of our findings. Second, combining individual generation of ideas with a group discussion of these ideas, as well as the context of heterogeneous groups, results in an ample and diverse selection of ideas, thoughts, and perceptions. Third, the concept mapping method has the added value of structuring qualitative data in a quantitative manner and visualizing the results.

Our study also has some limitations. First, generalizability could be affected because we only included participants from 1 of 12 Dutch provinces and most student participants were not randomly selected by their school. Also, professionals with-or experiencing - a heavier workload may have been underrepresented, as a busy work schedule was the most common reason not to participate. Additionally, the sample sizes of 2 of the professional concept mapping sessions were smaller than the recommended minimum number of 8 participants [42]. However, other studies using smaller sample sizes have been successful in applying the concept mapping method $[60,61]$. Furthermore, the online format used with the third group of professionals resulted in less interaction between professionals compared to the physical group meetings, potentially restricting the generation of new ideas. Nevertheless, this online concept mapping session generated the most statements of all sessions with professionals. It is possible data saturation regarding the professionals' perspectives has not been reached, although the themes generated in both the online and physical sessions were similar to each other. Due to time restrictions as well as the busy schedules of professionals, an additional concept mapping session was not feasible within our current study. Data saturation regarding the students' perspectives does appear to have been reached, as only one new theme emerged during the third concept mapping session with students.

\section{Future Activities}

The sixth and final concept mapping step, utilization of the maps, was not conducted in this study. However, the development of an actual online application, in which the 
perspectives of both professionals and students will be included, was already planned. The interpretation of clusters and concept maps generated in our current study proved helpful in deciding which statements or themes to include in the development of the online application. A selection of these themes will be translated into functionalities for a pilot version of the application that will be tested and evaluated with professionals and students from more cities and provinces than in our current study. We consider the online application development a co-creation process, collaborating with relevant stakeholders from needs assessment to development, testing, and (effect) evaluation $[62,63]$.

\section{Conclusion}

Both professionals and students were positive about an online application to support students in dealing with school absenteeism for medical reasons and to stimulate student autonomy and return to school. Better and easily accessible contact between students, parents, and professionals was a shared need for which an online tool is highly suited. Developing an online application to be used complementary to the MASS intervention could potentially stimulate and enhance the intervention's positive effects on school absenteeism.

\section{Acknowledgments}

This study was part of a project (736300012) granted by ZonMw, the Dutch Health research and care innovation fund.

\section{Authors' Contributions}

MH conceptualized the study, with the assistance of FS. RB and CE executed the concept mapping study, under the supervision of MH and FS. RB, CE, MH, and FS analyzed and interpreted the data. LD and MH wrote the first draft of the paper. All authors critically reviewed the manuscript and provided suggestions. MH finalized the manuscript. All authors have read and approved the final version of this manuscript.

\section{Conflicts of Interest}

None declared.

\section{Multimedia Appendix 1}

Overview of professionals' job functions (total $\mathrm{N}=23$ ).

[DOCX File, 15 KB-Multimedia Appendix 1]

\section{Multimedia Appendix 2}

Concept maps of the sessions with professionals. [DOCX File, 1112 KB-Multimedia Appendix 2]

\section{Multimedia Appendix 3}

Concept maps of the sessions with students. [DOCX File, 154 KB-Multimedia Appendix 3]

\section{References}

1. Allen C, Diamond-Myrsten S, Rollins L. School absenteeism in children and adolescents. Am Fam Physician 2018;98(12):738-744. [doi: 10.4324/9780203126622-7] [Medline: $\underline{30525360]}$

2. Pflug V, Schneider S. School Absenteeism: An Online Survey via Social Networks. Child Psychiatry Hum Dev 2016 Jun;47(3):417-429. [doi: 10.1007/s10578-015-0576-5] [Medline: 26374328]

3. Reid K. The strategic management of truancy and school absenteeism: finding solutions from a national perspective. Educational Review 2012 May;64(2):211-222. [doi: 10.1080/00131911.2011.598918]

4. Geoorloofd schoolverzuim en spijbelen [Excused school absence and truancy] 2020. Rijksoverheid Dutch Government. URL: https://www.rijksoverheid.nl/onderwerpen/leerplicht/geoorloofd-schoolverzuim-en-spijbelen [accessed 2020-07-10]

5. Statline 2018. Centraal Bureau voor de Statistiek (CBS) Statistics Netherlands. URL: www.statline.cbs.nl [accessed 2020-08-20]

6. Brief van Arie Slob aan de Tweede Kamer van 19 februari 2018 betreffende cijfers schoolverzuim [Government letter concerning numbers of school absenteeism]. Ministerie van Onderwijs, Cultuur en Wetenschappen. 2018. URL: https:/ /www.rijksoverheid.nl/documenten/kamerstukken/2018/02/19/ kamerbrief-over-cijfers-schoolverzuim-en-vrijstellingen-funderend-onderwijs [accessed 2020-07-10]

7. Christenson SL, Thurlow ML. School Dropouts. Curr Dir Psychol Sci 2016 Jun 22;13(1):36-39. [doi: 10.1111/j.0963-7214.2004.01301010.x]

8. Eckstein Z, Wolpin KI. Why Youths Drop out of High School: The Impact of Preferences, Opportunities, and Abilities. Econometrica 1999 Nov;67(6):1295-1339. [doi: 10.1111/1468-0262.00081] 
9. Kearney CA. School absenteeism and school refusal behavior in youth: a contemporary review. Clin Psychol Rev 2008 Mar;28(3):451-471. [doi: 10.1016/j.cpr.2007.07.012] [Medline: 17720288]

10. Rumberger RW. Why students drop out of school and what can be done. Dropouts in America: How severe is the problem? What do we know about intervention and prevention? Harvard University 2001:1-45 [FREE Full text]

11. Landelijke VSV cijfers [National numbers on drop-out in education]. Ministerie van Onderwijs, Cultuur en Wetenschappen. 2020. URL: https://www.onderwijsincijfers.nl/kengetallen/onderwijs-algemeen/leerlingen-en-studenten/ prestaties-voortijdig-schoolverlaten/landelijke-vsv-cijfers [accessed 2020-07-11]

12. Allison MA, Attisha E, COUNCIL ON SCHOOL HEALTH. The Link Between School Attendance and Good Health. Pediatrics 2019 Feb;143(2):1-13 [FREE Full text] [doi: 10.1542/peds.2018-3648] [Medline: $\underline{30835245}$ ]

13. Freudenberg N, Ruglis J. Reframing school dropout as a public health issue. Prev Chronic Dis 2007 Oct;4(4):A107 [FREE Full text] [Medline: 17875251$]$

14. Gase LN, Kuo T, Coller K, Guerrero LR, Wong MD. Assessing the connection between health and education: identifying potential leverage points for public health to improve school attendance. Am J Public Health 2014 Sep;104(9):e47-e54 [FREE Full text] [doi: 10.2105/AJPH.2014.301977] [Medline: 25033134]

15. Rumberger RW, Rotermund S. The relationship between engagement and high school dropout. In: Christenson SL, Reschly AL, Wylie C, editors. Handbook of research on student engagement. Secaucus, NJ: Springer Science; 2012:491-513.

16. Theunissen-Lamers MJ. Stay in or drop out: the pathways to school dropout from a public health perspective. Maastricht, the Netherlands: Datawyse / Universitaire Pers Maastricht; 2016.

17. Vanneste YTM, Feron FJM, van Mook MAW, de Rijk A. Towards a Better Understanding of Sickness Absence in Adolescence: A Qualitative Study among Dutch Intermediate Vocational Education Students. Biomed Res Int 2017;2017:1-9 [FREE Full text] [doi: 10.1155/2017/1064307] [Medline: 28573135]

18. Vanneste YTM. Reported sick from school: a study into addressing medical absenteeism among students. Maastricht, The Netherlands: Datawyse / Universitaire Pers Maastricht; 2015.

19. Hawkrigg S, Payne DN. Prolonged school non-attendance in adolescence: a practical approach. Arch Dis Child 2014 Oct;99(10):954-957. [doi: 10.1136/archdischild-2013-304595] [Medline: 24914097]

20. Global Accelerated Action for the Health of Adolescents (AA-HA!) Guidance to Support Country Implementation. World Health Organisation (WHO). 2017. URL: http://www.who.int/maternal child adolescent/topics/adolescence/second-decade/ en [accessed 2021-06-14]

21. Schoolverzuim in het Voortgezet Onderwijs [Report on school absenteeism in secondary school]. NIPO. 2002. URL: http:/ /www.tns-nipo.com/pages/persvannipo/pdf/schoolverzuim03.pdf [accessed 2020-07-10]

22. Gezondheidsmonitor Jeugd 2015 [Health Monitor Youth 2015]: Schoolverzuim [Schoolabsence]. RIVM [National Institute for Public Health and the Environment]. 2016. URL: https://www.volksgezondheidenzorg.info/onderwerp/ gezondheidsmonitor-jeugd/schoolverzuim [accessed 2020-07-10]

23. M@ZL op het vo [MASS in secondary schools]. RIVM [National Institute for Public Health and the Environment]. 2017. URL: https://interventies.loketgezondleven.nl/leefstijlinterventies/interventies-zoeken/1400718 [accessed 2020-08-12]

24. Vanneste YTM, Rots CMC, van de Goor LAM, Feron FJM. Medische Advisering Ziekgemelde Leerling door de jeugdarts (M@ZL): ontwikkeling van een interventie [Medical Advice for Sick- reported Students in secondary school by the youth health care physician (MASS): development of an intervention]. Tijds. gezondheids.wetenschappen 2012;90(7):412-419. [doi: $10.1007 / \mathrm{s} 12508-012-0145-2]$

25. Vanneste YTM, Mathijssen JJP, van de Goor LAM, Rots-de Vries CMC, Feron FJM. Extensive Medical Absenteeism among Secondary School Students: An Observational Study on Their Health Condition from a Biopsychosocial Perspective. OJPM 2015;05(03):111-121. [doi: 10.4236/ojpm.2015.53013]

26. Dam P, Prinsen B. Investeren in opvoeden en opgroeien loont. Kosteneffectiviteit van de preventie van pedagogische, psychosociale en psychosomatische problematiek door de jeugdgezondheidszorg [Investing in child rearing and child raising pays off. Cost-effectiveness of the prevention of pedagogical, psychosocial and psychosomatic problems by youth health care]. Actiz \& GGD Nederland. 2013. URL: https://vng.nl/files/vng/

201300912-brochure investeren in opvoeden en opgroeien loont.pdf [accessed 2020-07-08]

27. Vanneste YTM, Mathijssen JJP, van de Goor IAM, Rots-de Vries CMC, Feron FJM. Addressing medical absenteeism in pre-vocational secondary students: effectiveness of a public health intervention, using a quasi-experimental design. BMC Public Health 2016 Oct 21;16(1):1107 [FREE Full text] [doi: 10.1186/s12889-016-3718-1] [Medline: 27769205]

28. Bakker D, Kazantzis N, Rickwood D, Rickard N. Mental Health Smartphone Apps: Review and Evidence-Based Recommendations for Future Developments. JMIR Ment Health 2016 Mar 01;3(1):e7 [FREE Full text] [doi: 10.2196/mental.4984] [Medline: 26932350]

29. Nauta N. Complexiteit van samenwerken, het speelveld [Complexity of collaboration, the playing field]. In: Hammelburg R, Lubbers WJ, Nauta N, editors. Veranderende samenwerking in de zorg [Changing collaboration in health care]. Houten, the Netherlands: Bohn Stafleu van Loghum; 2014:23-26.

30. mHealth. New horizons for health through mobile technologies. World Health Organization. 2011. URL: https://www. who.int/goe/publications/goe_mhealth_web.pdf [accessed 2021-06-14] 
31. Oh H, Rizo C, Enkin M, Jadad A. What is eHealth (3): a systematic review of published definitions. J Med Internet Res 2005 Feb 24;7(1):e1 [FREE Full text] [doi: 10.2196/jmir.7.1.e1] [Medline: 15829471]

32. Green Paper on mobile Health ('mHealth'). European Commission. 2014. URL: https://digital-strategy.ec.europa.eu/en/ library/green-paper-mobile-health-mhealth [accessed 2020-08-12]

33. Whitehead L, Seaton P. The Effectiveness of Self-Management Mobile Phone and Tablet Apps in Long-term Condition Management: A Systematic Review. J Med Internet Res 2016;18(5):e97 [FREE Full text] [doi: 10.2196/jmir.4883] [Medline: 27185295]

34. Internettoegang en internetactiviteiten [Internet access and internet activities]. Centraal Bureau voor de Statistiek (CBS) [Statistics Netherlands]. 2020 Nov 18. URL: https://opendata.cbs.nl/\#/CBS/nl/dataset/84888NED/table?ts=1623344020676 [accessed 2021-06-10]

35. Bombard Y, Baker GR, Orlando E, Fancott C, Bhatia P, Casalino S, et al. Engaging patients to improve quality of care: a systematic review. Implement Sci 2018 Jul 26;13(1):98 [FREE Full text] [doi: 10.1186/s13012-018-0784-z] [Medline: 30045735]

36. Geryk LL, Roberts CA, Sage AJ, Coyne-Beasley T, Sleath BL, Carpenter DM. Parent and Clinician Preferences for an Asthma App to Promote Adolescent Self-Management: A Formative Study. JMIR Res Protoc 2016 Dec 06;5(4):e229 [FREE Full text] [doi: 10.2196/resprot.5932] [Medline: 27923777]

37. Burke JG, O'Campo P, Peak GL, Gielen AC, McDonnell KA, Trochim WMK. An introduction to concept mapping as a participatory public health research method. Qual Health Res 2005 Dec;15(10):1392-1410. [doi: 10.1177/1049732305278876] [Medline: 16263919]

38. Trochim WMK. An introduction to concept mapping for planning and evaluation. Evaluation and Program Planning 1989 Jan;12(1):1-16. [doi: 10.1016/0149-7189(89)90016-5]

39. Trochim WMK, Kane M. Concept mapping: an introduction to structured conceptualization in health care. Int J Qual Health Care 2005 Jun;17(3):187-191. [doi: 10.1093/intqhc/mzi038] [Medline: 15872026]

40. Bevolkingsontwikkeling per regio [Population development per region]. Centraal Bureau voor de Statistiek (CBS) [Statistics Netherlands]. 2018. URL: http://statline.cbs.nl/Statweb/publication/ ?DM=SLNL\&PA=37230ned\&D1=0,17\&D2=308\&D3=195-206,208-211\&VW=T [accessed 2021-06-10]

41. Hidding LM, Altenburg TM, van Ekris E, Chinapaw MJM. Why Do Children Engage in Sedentary Behavior? Child- and Parent-Perceived Determinants. Int J Environ Res Public Health 2017 Jun 22;14(7):1-27 [FREE Full text] [doi: 10.3390/ijerph14070671] [Medline: 28640232]

42. van Randeraad C, Severens P. Manual Ariadne 3.0. Minds21.org. 2015. URL: http://www.minds21.org/images public/ manual\%20\%20ARIADNE\%203.0\%20\%20april\%202015.pdf [accessed 2020-07-10]

43. Floch J, Zettl A, Fricke L, Weisser T, Grut L, Vilarinho T, et al. User Needs in the Development of a Health App Ecosystem for Self-Management of Cystic Fibrosis: User-Centered Development Approach. JMIR Mhealth Uhealth 2018 May 08;6(5):e113 [FREE Full text] [doi: 10.2196/mhealth.8236] [Medline: 29739742]

44. Marcolino MS, Oliveira JAQ, D'Agostino M, Ribeiro AL, Alkmim MBM, Novillo-Ortiz D. The Impact of mHealth Interventions: Systematic Review of Systematic Reviews. JMIR Mhealth Uhealth 2018 Jan 17;6(1):e23 [FREE Full text] [doi: 10.2196/mhealth.8873] [Medline: 29343463]

45. Attwood G, Croll P. Truancy in secondary school pupils: prevalence, trajectories and pupil perspectives. Research Papers in Education 2006 Dec;21(4):467-484. [doi: 10.1080/02671520600942446]

46. Fall A, Roberts G. High school dropouts: interactions between social context, self-perceptions, school engagement, and student dropout. J Adolesc 2012 Aug;35(4):787-798 [FREE Full text] [doi: 10.1016/j.adolescence.2011.11.004] [Medline: 22153483]

47. Roorda DL, Koomen HMY, Spilt JL, Oort FJ. The Influence of Affective Teacher-Student Relationships on Students' School Engagement and Achievement. Review of Educational Research 2011 Dec 01;81(4):493-529. [doi: $10.3102 / 0034654311421793$ ]

48. M. Strand A. 'School - no thanks - it ain't my thing': accounts for truancy. Students' perspectives on their truancy and school lives. International Journal of Adolescence and Youth 2012 Dec 11;19(2):262-277. [doi: 10.1080/02673843.2012.743920]

49. Paechter M, Maier B, Macher D. Students' expectations of, and experiences in e-learning: Their relation to learning achievements and course satisfaction. Computers \& Education 2010 Jan;54(1):222-229. [doi: 10.1016/j.compedu.2009.08.005]

50. Sher A. Assessing the relationship of student-instructor and student-student interaction to student learning and satisfaction in Web-based online learning environment. Journal of Interactive Online Learning 2009;8(2):102-120 [FREE Full text]

51. Gonzalez-DeHass AR, Willems PP, Holbein MFD. Examining the Relationship Between Parental Involvement and Student Motivation. Educ Psychol Rev 2005 Jun;17(2):99-123. [doi: 10.1007/s10648-005-3949-7]

52. Im MH, Hughes JN, West SG. Effect of Trajectories of Friends' and Parents' School Involvement on Adolescents' Engagement and Achievement. J Res Adolesc 2016 Dec;26(4):963-978 [FREE Full text] [doi: 10.1111/jora.12247] [Medline: 28239244]

53. Bosma AR, Boot CRL, Schaafsma FG, Kok G, Anema JR. Development of an Intervention to Create a Supportive Work Environment for Employees with Chronic Conditions: An Intervention Mapping Approach. J Occup Rehabil 2020 Dec;30(4):624-634 [FREE Full text] [doi: 10.1007/s10926-020-09885-z] [Medline: $\underline{\text { 32200483] }}$ 
54. Bouwsma EVA, Vonk Noordegraaf A, Szlávik Z, Brölmann HAM, Emanuel MH, Lips JP, et al. Process evaluation of a multidisciplinary care program for patients undergoing gynaecological surgery. J Occup Rehabil 2014 Sep;24(3):425-438 [FREE Full text] [doi: 10.1007/s10926-013-9475-4] [Medline: 24057871]

55. van Vilsteren M, van Oostrom SH, de Vet HCW, Franche RL, Boot CRL, Anema JR. Workplace interventions to prevent work disability in workers on sick leave. Cochrane Database Syst Rev 2015 Oct 05(10):CD006955. [doi:

10.1002/14651858.CD006955.pub3] [Medline: 26436959]

56. Årsand E, Frøisland DH, Skrøvseth SO, Chomutare T, Tatara N, Hartvigsen G, et al. Mobile health applications to assist patients with diabetes: lessons learned and design implications. J Diabetes Sci Technol 2012 Sep;6(5):1197-1206 [FREE Full text] [Medline: 23063047]

57. Beldarrain Y. Distance Education Trends: Integrating new technologies to foster student interaction and collaboration. Distance Education 2006 Aug;27(2):139-153. [doi: 10.1080/01587910600789498]

58. Ventola CL. Mobile devices and apps for health care professionals: uses and benefits. P T 2014 May;39(5):356-364 [FREE Full text] [Medline: 24883008]

59. $\mathrm{Wu} \mathrm{YP,} \mathrm{Hommel} \mathrm{KA.} \mathrm{Using} \mathrm{technology} \mathrm{to} \mathrm{assess} \mathrm{and} \mathrm{promote} \mathrm{adherence} \mathrm{to} \mathrm{medical} \mathrm{regimens} \mathrm{in} \mathrm{pediatric} \mathrm{chronic} \mathrm{illness.}$ J Pediatr 2014 Apr;164(4):922-927. [doi: 10.1016/j.jpeds.2013.11.013] [Medline: 24359939]

60. van Randeraad-van der Zee CH, Beurskens AJHM, Swinkels RAHM, Pool JJM, Batterham RW, Osborne RH, et al. The burden of neck pain: its meaning for persons with neck pain and healthcare providers, explored by concept mapping. Qual Life Res 2015 Oct 14;25(5):1219-1225. [doi: 10.1007/s11136-015-1149-6]

61. Kornet-van der Aa DA, van Randeraad-van der Zee CH, Mayer J, Borys JM, Chinapaw MJM. Recommendations for obesity prevention among adolescents from disadvantaged backgrounds: a concept mapping study among scientific and professional experts. Pediatr Obes 2018 Jun;13(6):389-392 [FREE Full text] [doi: 10.1111/ijpo.12239] [Medline: 28921882]

62. Martin A, Caon M, Adorni F, Andreoni G, Ascolese A, Atkinson S, et al. A Mobile Phone Intervention to Improve Obesity-Related Health Behaviors of Adolescents Across Europe: Iterative Co-Design and Feasibility Study. JMIR Mhealth Uhealth 2020 Mar 02;8(3):e14118 [FREE Full text] [doi: 10.2196/14118] [Medline: 32130179]

63. Whitehouse SR, Lam P, Balka E, McLellan S, Deevska M, Penn D, et al. Co-Creation With TickiT: Designing and Evaluating a Clinical eHealth Platform for Youth. JMIR Res Protoc 2013 Oct 18;2(2):e42 [FREE Full text] [doi: 10.2196/resprot.2865] [Medline: 24140595]

\section{Abbreviations}

MASS: Medical Advice for Sick-reported Students

mHealth: mobile health

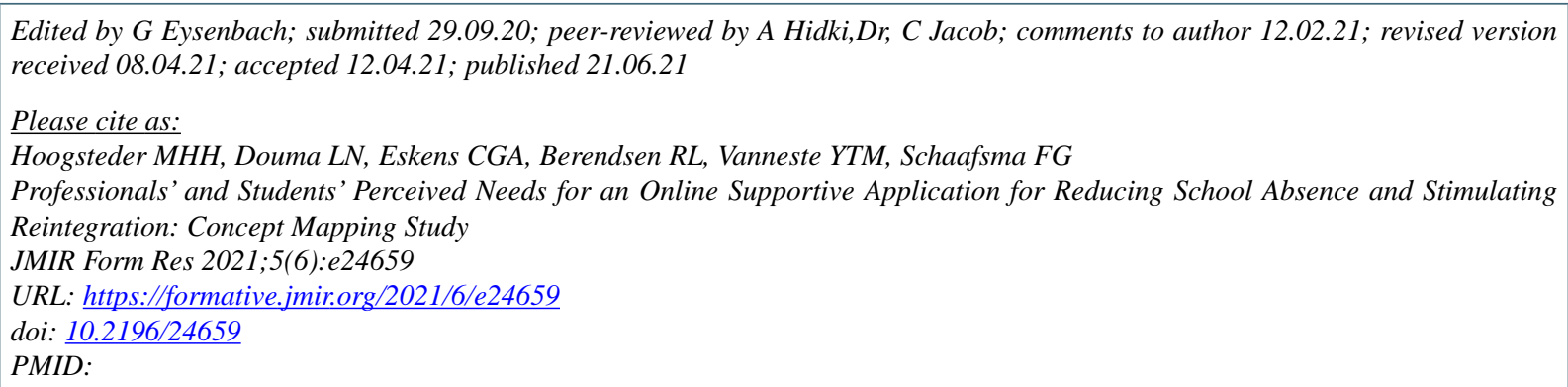

CMariette H H Hoogsteder, Linda N Douma, Charlotte G A Eskens, Renske L Berendsen, Yvonne T M Vanneste, Frederieke G Schaafsma. Originally published in JMIR Formative Research (https://formative.jmir.org), 21.06.2021. This is an open-access article distributed under the terms of the Creative Commons Attribution License (https://creativecommons.org/licenses/by/4.0/), which permits unrestricted use, distribution, and reproduction in any medium, provided the original work, first published in JMIR Formative Research, is properly cited. The complete bibliographic information, a link to the original publication on https://formative.jmir.org, as well as this copyright and license information must be included. 